\title{
Da castanha-do-pará ao ferro: os múltiplos impactos dos projetos de mineração na Amazônia brasileira
}

Stephen G. Bunker - Professor do Departamento de Sociologia da Universidade de Wisconsin - Madison.

\begin{abstract}
Resumo
O estudo envolve a análise da trajetória da produção regional tanto do minério de ferro quanto da castanha-dopará, produtos extrativos da Amazônia oriental brasileira. Indica que a mineração tornou-se uma importante atividade econômica, contrastando com a castanha-do-pará que perdeu sua expressão econômica. O estudo argumenta que estas trajetórias diferenciadas vinculam-se ao fato de a extração da castanha-do-pará não ser susceptível às mudanças tecnológicas diferentemente da estagnação do recurso mineral que envolve número maior de oportunidades de mudanças tecnológicas e de intensificação do capital.
\end{abstract}

\begin{abstract}
The study comprises the trajectory of the regional production both of the iron ore as well as Brazil nut, extractives products of the Brazilian Oriental Amazonia. It indicates that the mining activities became a important economic activities, once the Brazil nut had lost its economic expression. The study argument that such differentiated trajectories have linked concerning the fact that the Brazil nut extraction being not susceptible to the technological changes different of the mineral resource stagnation which involves a great number of opportunities of technological changes and intensive capital.
\end{abstract}

Palavras-chave

Minério de ferro; castanha-do-pará; recurso naturais e Amazônia.

\section{Keywords}

Iron ore; Brazil nut; natural resource the Amazonia. 


\section{INTRODUÇÃO}

O crescente aumento e a localização remota da extração mineral indicam que projetos de capital intensivo freqüentemente causam sérias rupturas nas economias e instituições regionais e retaliações de classe, que são apenas parcialmente integradas à economia capitalista mundial. A construção de uma grande infra-estrutura de transporte em áreas remotas atrai grandes contingentes de pessoas, em primeira instância, e estimula a migração, em segunda instância. Esse influxo de população combina-se com o impacto econômico e político de empresas de mineração e fundição em uma organização política e econômica local, preexistente. A organização política local é subjugada pela força muito maior das associações de estados nacionais e internacionais e de companhias e instituições financeiras. A pesada infra-estrutura das modernas extrações, do transporte e do processamento pode alterar dramaticamente o ambiente físico, limitando ou eliminando economias estabelecidas.

Os múltiplos impactos de uma grande mineração de ferro na Amazônia brasileira sobre uma organização econômica e política que girava em torno da extração e do transporte de um outro recurso natural - a castanha-do-pará - demonstram esse processo. Neste capítulo, seguiremos a estrada de ferro desde a boca da mina até o porto, mostrando como os sistemas de transporte podem reorganizar paisagens, classes sociais, instituições políticas, propriedades e relações trabalhistas.

\section{Máquinas na selva}

Na manhã do dia 28 de fevereiro de 1985, um homem, próximo a uma larga janela, pousava cada uma das mãos em uma grande alavanca. Na pequena e alta torre de metal acima de seu exíguo compartimento, um fluxo regular de minério de ferro de alta qualidade caía sobre uma longa esteira transportadora, enchendo e completando o profundo e estreito receptáculo sob o qual ele trabalhava. Pela janela, lá fora, um trem de 160 vagões abertos passava lentamente. Cada vez que um dos vagões passava pela janela, o homem acionava uma das alavancas, abrindo um orifício que derramava 50 toneladas de minério dentro do vagão, em menos de alguns segundos. Antes que o vagão pudesse percorrer uma distância maior do que a metade de seu próprio comprimento, ele acionava a outra alavanca, abrindo um segundo orifício para completar a carga deixada pela primeira. Conforme o final do vagão aproximava-se do início do primeiro orifício, o homem trazia a primeira alavanca de volta e depois fechava o segundo orifício justamente a tempo de evitar o derramamento de minério no espaço entre o vagão que ele acabara de encher e o vagão vazio, logo atrás. Ele abria o primeiro orifício outra vez, quase imediatamente após ter fechado o segundo. Apesar da velocidade com que ele trabalhava, cada vagão acabava com 
um montículo quase idêntico elevando-se acima das paredes laterais. De vez em quando, ele fechava um dos orifícios muito rápido, e o trem parava, dava uma pequena marcha a ré e recomeçava a suave operação.

A habilidosa velocidade, a coordenação precisa de suas mãos e olhos com os vagões que passavam e sua instantânea comunicação com o engenheiro do trem misturavam-se em total contraste com a força maciça do trem e o peso morto das exatas 97 toneladas que ele deixava cair em cada vagão. Se pudéssemos nos afastar o bastante para que nossa visão abrangesse a totalidade da esteira rolante, dos orifícios, da cabina do operador e do trem, as pesadas máquinas e seus movimentos em minuciosa sincronização contrastariam ainda mais com a paisagem mais além. Logo adiante da estrada de ferro, havia uma íngreme colina coberta pela vegetação exuberante e variada da floresta amazônica. Algumas das altas árvores tinham copas largas, cheias, de uma cor verde-escura, enquanto outras eram aquinhoadas e cercadas por grossos cipós que as cobriam completamente, do chão até o topo. O observador familiarizado com a selva amazônica era brindado com um raro prazer: a mata densa e fechada torna impossível ver a floresta através das árvores, mas aqui a colina rasgada expunha à vista a totalidade do vasto panorama, com suas múltiplas cores e formas.

Uma poderosa mistura de sons pesados aumentava o contraste entre as formas vegetais heterogêneas e o processo mecânico tão minuciosamente integrado. A floresta está quieta. O barulho dos pássaros é quase constante, mas seu som é baixo e espalhado, vindo de diferentes direções e distâncias. Aqui os barulhos mecânicos eram enormes, contínuos e envolventes; o ouvido tinha de esforçar-se para discernir os vários rugidos, chiados e rangidos que se amontoavam em um constante e grave som de trovão.

A incongruência entre o complexo maquinário ao pé da colina e a floresta virgem que se elevava acima dela era apenas a primeira de uma série de rupturas visuais e conceituais. Atrás do maquinário, elevava-se outra colina, igualmente íngreme e igualmente próxima à estrada de ferro, porém esta era vermelha, destituída de vegetação, cruzada por estradas largas e ladeadas por barrancos, circundando enormes construções de metal e concreto, conectadas por um ziguezague de grandes esteiras rolantes e tubos que corriam de três grandes armazéns de metal próximos ao topo da colina até os buracos lá embaixo, sobre a estrada de ferro. Enormes caminhões, cada qual capaz de transportar 170 toneladas de minério e terra, apareciam sobre o cume da colina, rapidamente davam a volta ao redor de três curvas fechadas até o mais alto dos três armazéns de metal e despejavam sua carga dentro de uma grande abertura quadrada em sua base, fazendo com que o minério começasse uma viagem colina abaixo, passando por três trituradores ou moedores, três peneiras e um tanque de lavagem 
até chegar aos pátios de estocagem, construídos ao longo da linha férrea, onde ele permaneceria até que a esteira transportadora o empurrasse para o tubo de carga.

Seguindo para o topo dessa colina, um ano e meio depois, poderse-ia olhar para baixo e ver dois largos e profundos barrancos. Seus lados quebrados por terraços em espirais descendentes de 15 metros de altura eram largos o suficiente para comportar não só os 12 caminhões subindo e descendo da cratera até os armazéns, mas também mais duas escavadoras maciças, cada uma capaz de arrancar 45 toneladas de minério, pedra e terra a cada mordida e encher os caminhões em três poderosas braçadas. Em um local mais abaixo, nesses terraços serpenteados, um perfurador fazia enormes buracos para as explosões em massa que soltariam a terra a ser retirada mais tarde. As crateras eram largas o bastante para que o grande pedaço de céu acima e o vasto poço de terra vermelha mais adiante diminuíssem o tamanho das grandes máquinas, vistas do outro lado.

As crateras cor de ferrugem, largas como eram, ocupavam apenas uma pequena parte de um planalto longo e estreito, que se estendia mais para o oeste. Diferente da selva exuberante e variada ao seu redor, a vegetação no topo dessa colina era esparsa e homogênea, na sua maioria gramíneas ralas e arbustos quebrados. E mesmo estes eram desiguais, pois toda a colina, com 4,5 quilômetros de comprimento, 300 metros de largura e 400 metros de profundidade, era composta de 66,7\% de minério de ferro, um dos mais puros do mundo. Levaria mais de duas décadas até que as duas escavadoras que já estavam trabalhando em 1986, juntamente com mais três que se juntaram a elas no decorrer dos 18 meses seguintes, pudessem terminar com essa colina e passar para outra montanha de metal dentre as muitas espalhadas por quase meio milhão de quilômetros quadrados, próximas da borda sul-oriental da floresta amazônica.

Do topo dessa colina era possível olhar para trás, para as colinas cobertas por florestas acima da torre de carregamento, para outro planalto pardo e para outra surpresa visual - uma bem construída cidade de escritórios, lojas, casas, armazéns, clubes atléticos e um hospital. Mesmo à distância, o desenho homogêneo e bem espaçado, bem como sua limpeza, distinguia-a da massa suja e periclitante que caracteriza a maioria das cidades da Amazônia. Uma inspeção mais detalhada mostraria que tudo aí era frugal, porém confortável, ordenado e funcional. Sua única concessão pública aos sentimentos era um DC-3 estacionado atrás de uma cerca branca, próximo ao clube dos trabalhadores. Um aviso em bonitas letras anunciava que essa aeronave era agora um monumento. Havia voado quase 8000 horas, trazendo os homens e equipamentos necessários para construir as primeiras instalações das minas, antes que a estrada fosse construída, através da floresta. Os diretores da companhia haviam aposentado o avião aqui, neste local de honra - um tributo da 
engenharia a uma das mais bem desenhadas, mais duráveis e funcionais máquinas de voar jamais construída.

Outra cidade estava sendo construída a doze quilômetros de distância, de tijolo e argamassa, ao invés de madeira e pregos. Conforme os empregados da companhia de mineração iam se mudando para a cidade permanente, deixavam os alojamentos temporários das companhias de construção e transporte subcontratadas. Eventualmente, a primeira cidade seria demolida para dar espaço às escavadoras, aos caminhões, às perfuradoras e a um novo conjunto de esteiras rolantes e plantas de beneficiamento que esvaziariam o terreno onde agora se achavam. Enquanto isso, ela proporcionaria apoio fundamental e o maior padrão de saúde e conforto da região.

As prodigiosas máquinas e a imensa força de trabalho mobilizadas para extrair esses minerais eram diminuídas pelas maciças montanhas e a cobertura florestal. Esta era a extremidade setentrional do grande planalto central brasileiro, e duas paisagens espetaculares sobrepunham-se. A crosta de ferro retardara a erosão milenar que rebaixou o resto do que eventualmente se transformou na floresta amazônica. A chuva e o vento cortaram profundos vales entre as montanhas de minério, mas ao mesmo tempo cobriram os aclives e sopés desses vales com o material mais frágil que puderam varrer dos leitos de ferro. Os solos, que uma vez cobriram as crostas de ferro, jaziam agora abaixo delas, sustentando uma vigorosa vida vegetal e animal nos vales e nos aclives abaixo dos cumes duros e com pouca vegetação (AB'SABER, 1982).

O declive acentua-se e uma estreita cadeia de montanhas elevase a 700 metros acima do nível do mar, lembrando, na forma, o antigo planalto do maciço central brasileiro, dramaticamente interrompido, árido e nu a 300 km ao sul, porém aqui coberto pela densa vegetação tropical, típica da floresta amazônica. A longa cadeia de montanhas, conhecida como Serra dos Carajás, é o centro fabulosamente rico daquilo que o governo brasileiro proclama como uma província mineral, compreendendo a maior parte do Sul do Pará, o mais oriental dos Estados da Amazônia brasileira. Ao todo, existem 18 bilhões de toneladas de minério em mais de uma dúzia de montanhas similares, suficientes para manter a projetada taxa de extração de 35 milhões de toneladas por ano por 547 anos. Essas grandes reservas de ferro estão associadas com pequenos, mas significativos, depósitos de manganês, a menos de $20 \mathrm{~km}$ ao norte da atual linha férrea, cobre de alta qualidade a cerca de duas vezes essa mesma distância, e ouro, níquel, titânio e bauxita, tudo dentro de um raio de cerca de $300 \mathrm{~km}$. Esses últimos minerais estão localizados em terreno menos alto e menos interrompido. A 10 km a leste da ferrovia, o solo da floresta desce para 200 metros acima do nível do mar, e vai descendo lentamente em direção ao rio Amazonas, 
que fica a $600 \mathrm{~km}$ ao norte, e aos rios Tocantins e Araguaia, a $150 \mathrm{~km}$ para o leste.

Embora esses minerais estejam concentrados perto de Carajás, eles afetaram profundamente a maior parte da região drenada por esses rios. Iniciativas públicas e privadas para explorar os minerais e a floresta estão transformando rapidamente a selva e sua esparsa população humana ao longo de uma área muito maior do que aquela que compreende os atuais depósitos de minerais.

Planejadores, políticos e empresários afiliados a bancos internacionais, ministérios, governos locais e empresas, desde as multinacionais até as locais, têm debatido por mais de uma década, uns com os outros e com intelectuais e ativistas, sobre como esses recursos deveriam ser explorados, se a extração dessa riqueza mineral melhoraria as condições de vida das populações empobrecidas do Estado do Pará e se a exploração econômica dessas novas economias seria suficientemente regulamentada para evitar a irreversível degradação do frágil ambiente tropical e a quebra da vulnerável integridade social e econômica das comunidades indígenas e camponesas que vivem nesse ambiente.

As respostas a tais debates residem em um complexo emaranhado de decisões e eventos políticos, econômicos e ecológicos, que começaram muito antes da descoberta do ferro e continuam muito após a primeira remessa de minério. Esses debates refletem as características econômicas e ambientais da extração de recursos naturais, que requer, freqüentemente, investimentos maciços de capital em áreas muito distantes de outras atividades econômicas. O enorme tamanho, a população esparsa, o isolamento e o relativo subdesenvolvimento da Amazônia potencializam essas características, no caso de Carajás. A inserção de um grande projeto mineral, com intensidade de capital, em uma área remota, produziu não somente uma incongruência visual entre as máquinas pesadas e a floresta densa, mas também um contraste mais abstrato entre as divisões de trabalho baseadas em salário, tecnicamente especializadas, minuciosamente coordenadas e espacialmente concentradas da organização de mineração e transporte de minério, e as formas de trabalho altamente dispersas, pouco diferenciadas e relativamente descoordenadas, com uma conexão muito tênue com uma economia monetária e literalmente nenhuma com a salarial, as quais haviam predominado nas áreas mais próximas de ocupação humana.

A superposição dessas duas economias - uma de capital intensivo e espacialmente concentrada, a outra espacialmente e socialmente difusa recriou nesse local isolado as desigualdades do poder econômico e político dentro dos mais amplos círculos de relações e interações do comércio e das finanças internacionais. Isso tudo estava enraizado na demanda por ferro e aço das economias industriais brasileira e internacional, mas também 
incluía a dependência financeira do Brasil do capital controlado externamente, tanto para investimentos na extração dos recursos de Carajás, como para investimentos na produção industrial em outras partes do país, mais urbanas e economicamente desenvolvidas.

Isso também refletiu mudanças políticas - especialmente a transição do governo militar para o civil, porém, mais significativamente, as variações do poder relativo dos governos federal e estadual - que tiveram seu ponto culminante durante a primeira remessa de minério. A organização social da mineração e sua relação com o meio ambiente natural no qual estava inserida emergiram de uma complexa interpolação de processos sociais, econômicos e ambientais, definidos por espaços que iam desde a economia local, densamente florestal, passando pela altamente politizada economia nacional, até a economia global, abstratamente comercial. A ferrovia reduziu o tempo necessário para ligar o espaço ao redor de Carajás ao resto do mundo e acelerou grandemente o tempo utilizado como medida de mudanças ou de velocidade para que um evento ocorrido em um determinado local afetasse eventos em outros locais. Sem dúvida, a história dos projetos de Carajás e de seus efeitos na floresta circundante é, em larga escala, a história da mudança das relações entre tempo e espaço, naquela área.

Descoberta, construção e migração em uma frente de recursos naturais

O todo complexo de uma organização de seres humanos e máquinas - jazida, cidade, instalações de beneficiamento, estradas e ferrovia -, que culminou com a primeira remessa de minério, em 1985, havia sido construído em um período recente e muito rapidamente. Dezoito anos e meio antes, em 31 de julho de 1967, um grupo de geólogos e engenheiros, funcionários da Companhia Meridional de Mineração, uma subsidiária brasileira da U.S. Steel, fez um vôo sobre o que era, então, uma floresta ininterrupta a oeste dos rios Araguaia e Tocantins, no sul do Pará. A região era habitada apenas ocasionalmente por pequenos grupos de índios Kayapó e atravessada, esporadicamente, pelas expedições de coletores de castanha-do-pará, que vinham do Rio Itacaiúnas, de Marabá, a cidade mais próxima, a mais de 150 km de distância, às margens do Tocantins.

A U.S. Steel estava preocupada com suas fontes de manganês africano, que estavam sendo ameaçadas pela instabilidade política, e sentiu-se encorajada a explorar essa remota e pouco conhecida parte da Amazônia, devido à descoberta de manganês, feita pela subsidiária da Union Carbide, na Serra do Sereno, a 50 km de Marabá, em 1966. Ao invés disso, no primeiro dia de pesquisa, os geólogos descobriram os cumes esparsamente cobertos de vegetação e, logo em seguida, confirmaram as suspeitas de que haviam encontrado um enorme campo de ferro. A Meridional entrou, imediatamente, com diversos pedidos de 
licença de exploração, que lhe teriam dado o direito de uso exclusivo da área, não fosse o Ministério das Minas e Energia, aparentemente alertado pelo extraordinário número e alcance geográfico dos pedidos, ter feito um esforço para entrar com uma parceria, juntamente com a Companhia Vale do Rio Doce (CVRD), uma empresa de mineração do setor público, com poucos acionistas do setor privado. O governo concedeu a ambas as companhias o direito de prospecção em 1969 (SANTOS, 1983).

A CVRD e a U.S. Steel formaram uma sociedade, em 1970, estabelecendo uma empresa em conjunto, a Amazônia Mineração, ou AMZA, para desenvolver e explorar os depósitos de Carajás. O governo emitiu vários decretos, em 1974, autorizando as operações de mineração e iniciaram-se os trabalhos de construção da ferrovia, começando em São Luís, uma cidade litorânea, a 900 km de Carajás, e, dois anos mais tarde, da rodovia, que começava em Marabá. Ao mesmo tempo, iniciaram-se os trabalhos da planta-piloto para beneficiar as primeiras amostras de minério para análise e remessa a possíveis compradores.

A U.S. Steel queria desenvolver a jazida de modo mais lento do que sua sócia brasileira e estava relutante em assumir sua parte nos enormes custos de construção da ferrovia. Por isso, os trabalhos nessas duas frentes prosseguiram com lentidão, no princípio. Em 1977, a CVRD comprou toda a parte da U.S. Steel na AMZA, porém começou a ter problemas para obter financiamento adicional. Em 1980, a CVRD dissolveu a AMZA e assumiu o controle direto sobre Carajás. Somente em 1982, quando a estrada para a jazida foi terminada e a CVRD obteve crédito suficiente do exterior para completar o projeto, o ritmo da construção aumentou.

Mesmo após o término da estrada, o acesso à área imediatamente próxima à jazida era fortemente controlado. A AMZA havia quebrado todos os precedentes ao solicitar não somente o direito aos minerais do subsolo concedido às companhias de mineração pelo governo federal, mas também o direito à propriedade da terra, a qual ela tentou comprar em 1974 do Estado do Pará, em cujo território se localizavam os depósitos de ferro. A propriedade direta daria à AMZA os instrumentos legais para evitar outras reivindicações quanto à terra e aos minerais e assim prospectar e explorar outros recursos, conforme sua conveniência. As reivindicações da AMZA compreendiam uma enorme área, de 469.000 hectares, bem maior do que a extensão dos minerais descobertos. A AMZA dizia que necessitava dessa área maior para outros projetos não minerais. Mais tarde, ao enfrentar oposição política quanto às suas reivindicações de terra, a AMZA anunciou que essa enorme área seria uma área de preservação ecológica e serviria como zona de proteção. O Estado do Pará enfrentou, então, uma reivindicação ilegal de terra, pressionado por uma poderosa corporação, com ligações diretas com o governo federal. Foi confrontado, também, com a única oportunidade 
de renda que a jazida poderia oferecer - a venda da terra. Controvérsias e dúvidas a respeito da venda da terra dificultaram a resposta do Estado.

Quando as negociações da AMZA com o Estado do Pará foram desaceleradas pelas lutas políticas locais, pelos entraves burocráticos e pelas denúncias de corrupção, os órgãos federais responsáveis pelos problemas de terra assumiram o controle direto sobre a área. A AMZA pôde, assim, levar suas reivindicações para a esfera federal, onde sua situação estava mais bem definida e suas relações com o governo eram mais previsíveis. Em 1985, apesar de suas reivindicações ainda estarem pendentes da aprovação pelo Senado, a CVRD conseguiu, efetivamente, proibir indivíduos ou companhias de ocupar e usar a terra. Ela conseguiu, de fato, realocar camponeses e pequenos agricultores que se haviam assentado anteriormente bem mais ao sul dos limites da área.

Assim, enquanto o trem corria com sua primeira carga de 11.500 toneladas de minérios de ferro e manganês, e após deixar para trás o grande lago construído para receber os detritos da lavagem dos minérios, percorria nove quilômetros até um vale, através de uma paisagem pouco modificada pelas monumentais construções e complexas atividades antrópicas da jazida. Ao emergir do vale e cruzar o rio Parauapebas, que corre ao longo do sopé das montanhas de Carajás, deixava a área controlada pela CVRD, entrando em uma paisagem completamente diferente, mais plana e radicalmente transformada pelos que ali se fixaram, mineradores e especuladores que haviam acorrido àquela área, procurando reivindicar alguma coisa daquela liberalidade da natureza, que as estradas e minas permitiriam extrair e vender. Aqui, contrastando com as atividades concentradas e extremamente organizadas da jazida, diretamente subordinadas a uma única companhia, milhares de indivíduos e famílias haviam imigrado por sua própria iniciativa, alguns buscando meios alternativos de sobrevivência, outros tentando obter uma fortuna ou aumentá-la. Pequenos fazendeiros vieram dos Estados de Goiás e Mato Grosso, bem como de outras partes do Sul do Pará, em busca de pastagens maiores e melhores, bem como para tirar vantagem do mercado de carne em potencial que os salários da jazida e das companhias de construção ao redor criariam. Camponeses sem terra vieram em busca de terrenos nas áreas de colonização, anunciadas pelos órgãos do governo. Especuladores de terra ouviram falar dos programas de colonização. Tentaram reivindicar extensas porções de terra para cortar e queimar para fazer pastagens, freqüentemente com uma pressa descuidada, a fim de vendê-las, mais tarde, aos órgãos de colonização. Alguns camponeses, que se assentaram nessas terras, tiveram de enfrentar os subseqüentes conflitos e negociações com o Estado e com os especuladores. Outros se assentaram em terras que foram mais tarde reivindicadas por fazendeiros, apoiados por grandes capitais e poderosas ligações políticas. A pequena presença do governo 
nas áreas de colonização oficial mitigou os abusos físicos, porém os camponeses que tinham de enfrentar fazendeiros e especuladores em outros locais eram muitas vezes vítimas da violência, tanto nas mãos de pistoleiros de aluguel, como nas mãos da polícia militar.

A fim de ter direito às terras sem dono, defendê-las contra outros posseiros, ou vendê-las a outros imigrantes, fazendeiros e camponeses tinham de ocupá-las, usá-las e melhorá-las. De acordo com a legislação brasileira, isso significava que tinham de desmatar a floresta em metade da área que reivindicavam. Por volta de 1985, grande parte daquilo que havia sido uma selva densa e ininterrupta entre Carajás e Marabá havia desaparecido, deixando apenas os troncos embranquecidos das maiores árvores que permaneciam no local das novas e extensas pastagens.

Mineradores também acorreram à área, atrás dos relatos e rumores sobre novas descobertas de ouro, levantando seus periclitantes acampamentos, jogando fortes jatos de água nas margens dos rios e igarapés e depois bombeando a lama pelos diques para separar a preciosa sujeira da eventual pepita. Os fazendeiros lutaram, individualmente, para evitar a mineração em suas terras, mas raramente podiam resistir às grandes hordas de homens atraídos pelas novas descobertas. Madeireiros apressaram-se a montar suas serrarias, comprando a preço barato dos fazendeiros e camponeses as grandes árvores que ainda permaneciam após as pequenas árvores terem sido derrubadas e queimadas. Os novos proprietários de terra utilizaram essa madeira morta como grandes e alvas poupanças, a ser transformadas em moeda corrente, quando necessário. Os pesados caminhões madeireiros rapidamente arruinaram as precárias estradas dentro das áreas de colonização, tornando as viagens até o mercado ou o hospital ainda mais difíceis. Comerciantes e caminhoneiros começaram a tirar vantagem da nova demanda por bens de consumo nas cidades que nasciam ao longo da estrada.

Cinco quilômetros rio acima, após a ponte da estrada de ferro, onde a nova estrada cruzava o Parauapebas, logo além dos limites das terras reivindicadas pela companhia, a CVRD havia construído uma outra pequena cidade planejada para alguns de seus funcionários de apoio. Essa pequena comunidade foi rapidamente esmagada por uma aglomeração espontânea de trabalhadores à procura de emprego, de comerciantes à procura de fregueses e de prostitutas que, inevitavelmente, aparecem onde grandes grupos de homens, ganhando muito mais do que a média local dos salários, se amontoam, longe de suas famílias. Parauapebas havia crescido de três casas, em 1980, para mais de 15.000 habitantes, por volta de 1985; seus precários serviços de água, esgoto, saúde e educação não poderiam servir sequer a um quinto dessa população. A sujeira, a desordem e o perigo eram diametralmente opostos à organização cuidadosamente controlada da comunidade planejada no 
topo da serra em frente à jazida; entretanto, essa cidade não planejada e a caótica paisagem ao seu redor eram um produto da jazida, tanto quanto sua bem-ordenada contraparte no cume da serra.

A CVRD não criou a distribuição enormemente desigual de terra e oportunidade de trabalho no resto do Brasil, que fez com que essa nova frente parecesse tão atraente, apesar de suas dificuldades óbvias, mas as atividades da companhia haviam estimulado diretamente o afluxo da população para a área. É verdade que alguns fazendeiros e camponeses chegaram ao local antes que a estrada e a ferrovia estivessem terminadas, e nenhum deles havia sido diretamente convidado pela companhia, porém todos os imigrantes chegaram até lá devido à promessa de terras e emprego oferecidos pela estrada e pela jazida. A CVRD importou trabalhadores para dentro dessa região remota, e suas políticas de habitação encorajaram os homens a vir trabalhar, não acompanhados de suas famílias. O desequilíbrio resultante da disparidade entre os habitantes masculinos e femininos na comunidade planejada contribuiu diretamente para a demanda por prostituição na cidade não planejada, tão deplorada pelos diretores da jazida. A companhia havia subcontratado a maior parte do trabalho de construção da própria jazida e continuou a subcontratar alguns dos trabalhos de manutenção na jazida e na cidade. Os funcionários das firmas contratadas tinham, freqüentemente, salários mais baixos do que os dos empregados da CVRD e não recebiam os mesmos benefícios de habitação; portanto, muitos deles viviam em Parauapebas, intensificando a demanda por casas e exacerbando o desequilíbrio entre a população masculina e a feminina.

Não era culpa da CVRD se o município de Marabá, em cujo território se situa Carajás, tinha um orçamento pequeno, inadequado até mesmo para sua população em 1970, mas a jazida havia sido a principal força que estimulou o crescimento de $17 \%$ ao ano na população do município, durante 15 anos, grande parte da qual longe do centro urbano de Marabá. O governo municipal não podia expandir seus minguados serviços sociais para atender os habitantes de Parauapebas; na realidade, estava enfrentando severas crises orçamentárias na própria cidade de Marabá.

Os diretores da jazida temiam a violência da luta pelas novas terras. Tentaram reduzir a ameaça de assentamentos ilegais e atividades mineradoras na área reivindicada pela CVRD, promovendo colônias agricultoras planejadas ao redor daquele perímetro. Os órgãos estaduais e federais eram os responsáveis pela solução dos conflitos de terra em uma área muito maior do que o interior da jazida. Esses órgãos tinham muito menos dinheiro e muito menos agentes e veículos para tratar desses assuntos de forma adequada. As necessidades e exigências da companhia esvaziaram ainda mais os limitados recursos dos órgãos governamentais. O projeto de engenharia, extremamente organizado, eficiente e seguro no topo da serra, permaneceu, assim, uma ilha 
fortemente defendida em meio a um mar de desordem, destruição, violência e pobreza, que suas próprias atividades trouxeram à região.

A caótica luta pela terra e pela sobrevivência era complicada ainda mais pelas variadas bases legais do controle da propriedade que os diversos grupos utilizavam para reivindicar as terras que haviam desmatado e pelas diferentes jurisdições dos órgãos governamentais, que tentavam regularizar os conflitos. Ao norte e a oeste da ponte da ferrovia sobre o rio Parauapebas, havia uma longa faixa de terra sob o controle do Instituto de Terras do Estado do Pará (ITERPA). Essa faixa fazia parte de uma área maior, chamada "Ampulheta", uma longa região com uma cintura extremamente estreita e largas saliências nas duas extremidades, que haviam sido excluídas quando o governo federal passou a controlar a maior parte das terras ao redor de Carajás. Anteriormente, todas as terras públicas pertenciam aos governos estaduais, porém, em 1971, o governo federal tomou para si a jurisdição sobre quaisquer terras em uma faixa de duzentos quilômetros de cada lado ao longo de todas as rodovias federais construídas, em construção ou planejadas na Amazônia. Quando as tentativas da AMZA para a compra da grande área de terra reivindicada ao ITERPA pareciam arrastar-se muito lentamente pelos procedimentos bastante imprecisos do Instituto de Terras, em 1976, o governo federal anunciou de modo repentino que uma nova rodovia seria construída. A área solicitada pela AMZA situava-se inteiramente dentro dos $200 \mathrm{~km}$ de largura ao longo de seu projetado trajeto .

A rodovia jamais progrediu além das linhas traçadas no mapa do governo, e ninguém jamais interpretou o fato como algo diferente de um mecanismo utilizado pelo governo para controlar Carajás. A Ampulheta - um vão estreito entre largas faixas que se estendiam para fora de várias rodovias federais, reais e imaginadas - era o estranho resíduo administrativo dos embotados instrumentos de uma tomada de terra por parte do governo federal. Essa faixa relativamente pequena estava situada longe das outras terras controladas pelo Estado do Pará e, portanto, era muito difícil chegar-se até ela e muito onerosa sua administração. Sua localização, entretanto, preocupava a CVRD, que era bastante poderosa para dar-lhe prioridade perante os órgãos de terra federais e estaduais.

A extremidade nordeste da Ampulheta situava-se logo após a área reivindicada pela CVRD e a apenas $20 \mathrm{~km}$ ao norte da crescente aglomeração de migrantes pobres e sem terra ao redor de Parauapebas.

\footnotetext{
${ }^{1}$ Os dados sobre a campanha da AMZA e da CVRD para obter o controle sobre essas terras encontram-se nos arquivos dos escritórios do ITERPA, do Instituto Nacional de Colonização e Reforma Agrária (INCRA) e Grupo Executivo das Terras do Araguaia-Tocantins (GETAT), em Belém e Marabá. Foram ainda obtidos em entrevistas com funcionários desses órgãos e com o pessoal da CVRD. O Liberal e A Província do Pará, os dois maiores jornais de Belém, cobriram o desenrolar do drama com bastantes detalhes.
} 
Sua posição privilegiada tornava-a um alvo para os grandes e poderosos fazendeiros e especuladores de terra de outras partes do Pará, bem como para os migrantes na área ao redor de Parauapebas. O ITERPA, o pequeno, fraco, mal organizado e freqüentemente corrupto Instituto de Terras do Pará, geralmente favorecia os grandes proprietários de terra e não podia ou não queria agir para controlar a violência que eles perpetravam contra os camponeses que começavam a ocupar a área.

A jurisdição sobre a área circundante recaía sobre o GETAT, um órgão de terras federal, com poderes especiais e legais, estabelecidos em 1980, para resolver conflitos violentos sobre terras, que as atividades da CVRD haviam estimulado e que ameaçavam o ordenado desenvolvimento de seus planos. O GETAT tinha poderes para expropriar terras em caso de tensão social. Foi legalmente criado para limitar as pretensões dos grandes grupos, que zombavam patentemente das restrições impostas pelo governo federal quanto ao tamanho das propriedades, dividindo a terra em vários lotes, em nome de diferentes pessoas, sob o controle de uma mesma família. O GETAT não podia atuar dentro da jurisdição do ITERPA, mas os conflitos na Ampulheta estendiam-se até a área de ação do GETAT, e a CVRD continuava a pressioná-lo para resolver os conflitos.

As tentativas do GETAT para colaborar com o ITERPA foram malogradas pela mútua desconfiança entre os órgãos e pela necessidade que o ITERPA tinha de preservar a pouca autonomia que ainda lhe restava. Para complicar ainda mais a situação, ambos os órgãos, o federal e o estadual, enfrentavam a incerteza do rápido retorno ao governo civil e a possibilidade de reforma agrária; portanto, qualquer ação poderia ser anulada por posteriores mudanças na política.

Mais ao sul, no longo e largo vale que continha a cidade de Parauapebas, pequenos fazendeiros haviam-se estabelecido ao longo das linhas onde achavam que as rodovias seriam construídas. Geralmente, dentro do limite de 3.000 hectares estabelecidos pela lei federal. Alguns haviam comprado terras de proprietários de arrendamentos de longo prazo de áreas de castanha-do-pará, de propriedade do governo estadual. Mais facilmente acessíveis do que a Ampulheta devido à estrada, eram também mais suscetíveis ao policiamento. A maior parte dos pretendentes a essas terras viviam e trabalhavam nelas. Haviam sido, portanto, poupados da violência social e do desperdício ambiental que estava destruindo a área mais ao norte.

Um pouco mais para o sul, mas também fora da área da CVRD, o GETAT havia estabelecido uma série de projetos de colonização planejada, em 1982 e 1983, nos quais os camponeses foram assentados em lotes de 50 hectares. O apoio técnico havia sido extremamente deficiente. Por falta de conhecimento ou de interesse, o GETAT distribuiu terras com pouco potencial para a agricultura ou mesmo para residência. 
Em algumas áreas assentadas, a fonte mais próxima de água estava a mais de $3 \mathrm{~km}$, e, em outras, a maior parte do solo era rochosa ou com pouca drenagem. Uma grande área jamais teve a ponte e a estrada especificadas nos planos originais. Conseqüentemente, muitos dos colonos venderam suas terras de volta aos fazendeiros, de quem eles as haviam originalmente apropriado, ou a outros migrantes mais recentes ou mais prósperos. Eles então se juntaram ao crescente grupo dos sem-terra e desempregados em Parauapebas, que estavam reivindicando o acesso às terras da Ampulheta.

A ferrovia passava ao sul da Ampulheta - cerca de 5 milhas ao norte de Parauapebas - através de uma faixa de grandes latifúndios, cujos poderosos proprietários haviam mantido os sem-terra ao largo. Por $14 \mathrm{~km}$ além do rio, o trem corria através de uma série de grandes lotes em nome de diferentes membros da família Lunadrelli, ricos industriais de São Paulo, que estavam entre os maiores beneficiários dos incentivos fiscais estabelecidos em 1966 para encorajar a criação de gado e outros empreendimentos em larga escala na Amazônia. Os $40 \mathrm{~km}$ seguintes da ferrovia cruzavam latifúndios ainda maiores, em nome de diferentes parentes de Pedro Miranda, um fazendeiro do Estado de Goiás, que comprara 105.000 hectares do Estado do Pará, em 1976, no que teria sido então floresta virgem, situada no triângulo entre o rio Parauapebas, correndo ao norte, e o rio Itacaiúnas, correndo a leste, para o qual o Parauapebas corria. O Sr. Miranda havia aberto primeiro picadas e depois estradas, desmatando extensas áreas de terra para pasto. Sua reputação de grande engenhosidade e respostas duras aos desafios ao seu controle estava bem estabelecida quando a estrada para a jazida abriu a área mais para o sul; grandes e pequenos pretendentes a terras evitaram essa área e procuraram opções menos perigosas.

Os primeiros $63 \mathrm{~km}$ de sua jornada levavam o trem carregado de minério através de uma paisagem que havia permanecido virtualmente imutável pela ocupação humana antes da descoberta das reservas de ferro e das promessas de prosperidade, que a previsão de exploração oferecia aos fazendeiros, agricultores e mineradores. As mudanças ocorridas nessa paisagem haviam sido rápidas e violentas, e muitas vezes também perdulárias e destrutivas, porém, como haviam ocorrido em uma área quase isenta de ocupação humana ou de economia anterior, os competidores por propriedade de terra e recursos eram todos, de uma certa forma, participantes da mesma nova economia regional, não importando o quão caótica era essa economia.

Porém, após deixar as terras do Sr. Miranda, o trem continuava a nordeste em uma região bastante estruturada por uma economia de mercado mais antiga, cuja mão-de-obra, propriedade e relações de troca eram muito diferentes daquelas onde os mineradores, construtores de estradas, fazendeiros e agricultores trabalhavam e negociavam. Essa 
região era a vasta área de castanhais, que, até recentemente, havia proporcionado a base da magra economia monetária da região e era ainda a base do controle político e econômico de uma agora ameaçada oligarquia local. Aqui o trem corria próximo ao rio Itacaiúnas, que havia desde há muito servido como a única via de acesso e transporte para os castanhais. Essas terras haviam sido reivindicadas como propriedade e exploradas pelo valor de troca muito antes do Sr. Miranda reivindicá-las para si.

Diferentemente da maioria das árvores na Amazônia, as árvores de castanha-do-pará são encontradas em enclaves relativamente densos. Eles são particularmente extensos ao redor de Marabá. Os castanhais e as populações que colhiam os frutos haviam fornecido matéria-prima às economias locais, nacional e internacionais desde o início do século. As terras haviam sido divididas entre poderosas famílias de políticos comerciantes, muito antes da descoberta de Carajás. A organização social e econômica que sustentava esse controle já havia experimentado várias rupturas profundas e turbulentas nos 25 anos anteriores à passagem do primeiro trem, porém essas famílias haviam derrotado a maioria desses desafios anteriores. A jazida e as empresas que os minérios haviam trazido para a área haviam terminado sua ascendência econômica, e uma enxurrada de novos órgãos e programas governamentais trouxeram indivíduos, grupos e associações que eles não podiam controlar politicamente. Mesmo assim, as velhas famílias ainda controlavam uma grande parte das terras, eram ainda bastante poderosas para manter uma boa parte delas e já começavam a obter vantagens comerciais das novas forças econômicas e sociais que haviam quebrado sua hegemonia.

\section{A economia da castanha-do-pará}

Até 1960, Marabá havia sido um porto fluvial isolado. A oligarquia local havia combinado o controle sobre a terra, a mão-de-obra, o comércio e a política para assegurar sua hegemonia e garantir seus lucros contínuos. Desde 1920, quando uma enxurrada de borracha cultivada da Malásia acabou com o quase monopólio da Amazônia sobre essa importante matéria-prima, até 1960, quando novas estradas e as políticas de desenvolvimento começaram a quebrar o isolamento de Marabá, a economia da região girava em torno da extração e da venda de castanha-do-pará de grandes castanhais nativos, que cobriam mais de um milhão de hectares, em todas as direções a partir de Marabá. Os rios forneciam o principal meio de transporte para dentro e para fora dos castanhais, e a localização de Marabá na confluência dos rios Itacaiúnas e Tocantins permitia o controle quase total do tráfego. Algumas famílias poderosas controlavam as casas de comércio que

\footnotetext{
${ }^{2}$ Marília Emmi (1987) fornece um vasto background sobre a economia da castanha-do-pará e a política em Marabá. Os dados adicionais foram obtidos em entrevistas com comerciantes, arrendatários, políticos e organizadores trabalhistas, em Marabá e Belém.
} 
compravam castanha-do-pará e remetiam o produto rio abaixo para exportação. Essas mesmas famílias dominavam a política da região, com uma rotatividade de cargos políticos, conforme os grupos políticos aos quais eram afiliados perdiam ou ganhavam o controle do governo do Estado. Essas alianças eram usadas para controlar o arrendamento dos castanhais do Estado do Pará e assim monopolizar a extração da safra. Esses grupos também dirigiam as ações do destacamento estadual local da polícia militar.

O restante da população local vivia na direta dependência dessas famílias. Seu principal acesso ao dinheiro e aos suprimentos era por meio do comércio da castanha-do-pará. Poucas pessoas podiam colher ou vender a castanha, a não ser que fossem subordinadas aos grandes proprietários de terra. Desafiar o controle dessas famílias sobre a terra e o comércio era muito difícil e perigoso; as grandes famílias brigavam entre si, porém a real ameaça de violência fatal forçava os camponeses da área a respeitar a oligarquia local e seu controle sobre a terra e os mercados.

A violência era também o último recurso eficaz para fazer valer as relações trabalhistas. Os comerciantes locais controlavam os trabalhadores por meio do fornecimento das ferramentas e das provisões necessárias para uma longa estada nos castanhais, no início da estação das chuvas, quando as castanhas começam a cair das árvores, para depois descontarem o preço desses bens do valor das castanhas colhidas. Os comerciantes estabeleciam os preços tanto dos bens comprados, como da castanha vendida. Controlavam, também, os barris utilizados para medir a colheita de cada trabalhador. A maioria dos trabalhadores terminava a colheita com débitos a ser transportados para a temporada seguinte. Empregados armados, pagos pelos comerciantes, impediam as tentativas de esconder ou contrabandear parte da mercadoria para fora do castanhal. O isolamento físico de Marabá dava mais força a essa oligarquia local, mantendo à distância os rivais mais fortes, enfrentando apenas os mais fracos e a resistência pouco organizada da mão-de-obra praticamente cativa, enviada aos castanhais para trabalhar em condições primitivas, insalubres e muitas vezes perigosas, durante a colheita, e abandonada aos seus próprios e magros recursos durante a estação da seca.

A construção de uma rodovia, ligando Brasília, a nova capital federal construída no planalto Central, a Belém, capital do Estado do Pará e o maior porto amazônico, em 1959, com um braço até Marabá, abriu a área para viagens por terra, trazendo uma enxurrada de migrantes em busca de terras e empregos. O controle da velha oligarquia era suficientemente forte para manter a velha economia imutável por mais uma década e meia; na realidade, o afluxo de camponeses pobres oferecia mão-de-obra adicional durante a época da colheita da castanha-do-pará.

Outras mudanças, porém, começaram a solapar o controle político, que garantia a força econômica da oligarquia, logo após a construção 
da rodovia. Em 1964, a ditadura militar assumiu o governo federal, reduzindo grandemente a força dos Estados. O regime militar depôs o Prefeito, que era também o maior e mais temido comerciante de castanha-do-pará, depondo, em seguida, seu filho da Assembléia Estadual. Em 1968, o governo militar estendeu seus programas de incentivo fiscal até a Amazônia para incluir fazendas de larga escala. Esses subsídios não eram muito utilizados em Marabá. Os castanhais já tinham proprietários e, portanto, não ofereciam grandes áreas de terra favorecidas pelos incentivos fiscais para a pecuária; entretanto, os incentivos trouxeram um comércio rico e poderoso para a área controlada, anteriormente, pelos políticos comerciantes.

Então, em 1970, o governo federal iniciou a construção da Rodovia Transamazônica, cortando o Brasil desde a costa leste até a fronteira ocidental com o Peru e anunciou seus planos de utilizar a nova rodovia para projetos de colonização, a fim de acalmar as tensões políticas e sociais causadas pela distribuição extremamente desigual de terra em outras regiões do país. Esse novo programa de assentamento de camponeses sem terra na Amazônia, juntamente com as crescentes preocupações com os conflitos de terra que os incentivos fiscais para grandes fazendas haviam estimulado, motivaram o decreto presidencial de 1971, que concedeu ao governo federal o controle sobre todas as terras devolutas em um cinturão de $200 \mathrm{~km}$ ao longo das rodovias federais construídas, em construção ou planejadas. Um novo órgão federal, o Instituto Nacional de Colonização e Reforma Agrária (INCRA), foi criado para administrar essas terras, dirimir disputas quanto à sua propriedade, regularizá-las e administrar os projetos de colonização. Essas medidas retiraram o controle sobre as terras devolutas das mãos dos governos estaduais, que as haviam controlado desde 1891.

A Rodovia Transamazônica passava bem ao norte de Marabá, e um dos primeiros projetos de colonização foi estabelecido nos limites setentrionais dos castanhais. Marabá tornou-se o centro administrativo dos novos projetos de colonização situados ao longo da rodovia, servindo como refúgio temporário para os camponeses que realmente haviam recebido terras e um abrigo mais permanente, embora precário, para o número bem maior de camponeses que vinham em busca de terras, porém não as receberam.

Os novos programas e políticas do governo federal restringiram o controle da oligarquia local sobre a terra e introduziram órgãos federais poderosos e burocráticos em uma área onde essa oligarquia havia exercido uma inquestionável influência política. O INCRA estabeleceu escritórios em Marabá. A Superintendência de Desenvolvimento da Amazônia (SUDAM), o órgão responsável pela administração dos programas de incentivos fiscais e por uma série de outros programas de desenvolvimento social, concentrou muitos desses programas ao 
redor de Marabá. Esses órgãos eram muito mais fortes e possuíam muito mais recursos do que a oligarquia local jamais havia conseguido.

Ao norte, sul e leste de Marabá, iniciaram-se conflitos entre pequenos proprietários, que detinham o usufruto da terra, e os fazendeiros que buscavam legalizar seus títulos sobre largas faixas de terra, expulsando os ocupantes originais. Os conflitos tornaram-se violentos logo após a abertura das estradas na área até os novos assentamentos. O controle dos comerciantes de castanha-do-pará estava seguro, e sua capacidade de organizar retaliações violentas era suficientemente temida para que os camponeses não os encurralassem e os fazendeiros procurassem terras mais baratas, não oneradas pelos direitos de uso detidos pelo poderoso grupo.

O início dos trabalhos nas minas de Carajás, a construção da estrada e da ferrovia e os rumores em todo o país de que havia empregos e oportunidades econômicas a ser exploradas aceleraram o fluxo de migrantes para uma área onde a maior parte da terra disponível já havia sido objeto de disputas. Por volta de 1976, ocorreu o primeiro conflito direto entre os proprietários de castanhais e camponeses sem terra. Rapidamente esses conflitos tornaram-se violentos, pois sua proliferação encorajava novas invasões de terras por parte dos camponeses e uma resistência mais determinada por parte dos proprietários de terra. Os conflitos de terras intensificaram-se, pois Carajás atraía mais pessoas à procura de emprego em Marabá, ao mesmo tempo que as novas estradas que levavam a Carajás tornavam os velhos castanhais mais acessíveis, especialmente durante a estação da seca, quando os proprietários não tinham muitas razões para controlá-los.

A crescente violência preocupava sobremaneira a CVRD e o governo federal. O governo tentava auxiliar a CVRD em suas tentativas de atrair investimentos do exterior para preencher o buraco financeiro deixado pela saída da U.S. Steel e estava colaborando com a companhia para atrair outras formas de investimento na região. Um grupo de consultores japoneses, contratados pelo governo do Japão para fazer uma análise de mercado para minerais na área e criar novos planos de desenvolvimento para a região, indicou, em 1979, que seria muito difícil atrair investimentos para a região enquanto houvesse tantos conflitos violentos. No ano seguinte, o governo federal estabelecia o GETAT, um novo órgão de terras diretamente subordinado ao Conselho de Segurança Nacional, que era, por sua vez, diretamente controlado pelos militares. A jurisdição do GETAT ultrapassava a do INCRA, e seus poderes executivos eram também muito maiores; porém, a área de atuação do GETAT estava limitada às áreas afetadas pelas minas e pela infraestrutura ao redor delas.

A declaração de controle federal sobre as terras devolutas na Amazônia e a subordinação dessas terras primeiro ao INCRA, em 1971, 
e depois ao GETAT, em 1980, correspondia a um aumento de centralização de poder no governo federal e a um enfraquecimento dos governos estaduais. Significava, também, um crescente envolvimento direto dos militares e uma preferência por formas de organização militar na Amazônia, especialmente em Carajás. O GETAT combinava as funções de planejamento, execução e legislação dentro de um único órgão. Ele atuava, essencialmente, como força de polícia, mas também como força econômica e de legalização das terras e de seus ocupantes. Estava manifesta a intenção do governo federal de assumir e controlar o desenvolvimento de uma economia mineral e o interesse mais profundo da CVRD no Pará.

Os poderes do GETAT, porém, eram restringidos nas cercanias de Marabá pelos arrendamentos dos castanhais, resíduos de um antigo sistema econômico e de suas relações com um sistema político menos centralizado, criado e sustentado pelo isolamento de Marabá. Diferentes famílias reivindicavam os castanhais, em muitos casos utilizando um acordo especial de arrendamento, que o Estado do Pará havia criado especificamente para os castanhais. Esses acordos excluíam os castanhais de castanha da categoria de terras devolutas; a fim de arrendá-las, o Estado havia, implicitamente, estabelecido uma propriedade. Assim, os castanhais continuaram sob a jurisdição do ITERPA, mesmo após a criação do GETAT. A força política do GETAT em Marabá e sua autoridade para conter conflitos, juntamente com a natureza sazonal da economia da castanha e as medidas totalmente diferentes de tempo e espaço utilizadas pelo GETAT e pelo Estado do Pará para defender a propriedade da terra, levaram a complexas intercalações, justaposições e oposição das atividades do GETAT e do ITERPA. Diferentes grupos de camponeses, fazendeiros e arrendatários de castanhais de castanha-do-pará tentaram utilizar a força, a fraqueza e as ambigüidades jurisdicionais de cada órgão em seu favor.

Embora os direitos de uso privado dessas terras tenham sido registrados por muitos anos, haviam sido explorados apenas de forma sazonal. A economia da castanha havia encorajado uma forma ausente de propriedade. Distantes das cidades e acessíveis apenas quando as mesmas chuvas que derrubavam as castanhas das árvores enchiam também os rios, essas áreas permaneceram como locais de preservação privados. Os arrendatários enviavam a mão-de-obra temporária, obrigada pelos débitos, para colher as castanhas e trazia-a de volta pelos rios. Enquanto as terras eram utilizadas apenas para a colheita da castanha e os esparsos postos de abastecimento, para os poucos camponeses que os proprietários permitiam ficar no local entre as safras, o controle sobre as terras podia ser mantido por meio do controle do transporte fluvial, que trazia as castanhas rio abaixo. Como a cidade de Marabá está situada no ponto onde o rio Itacaiúnas deságua no Tocantins, os proprietários dos castanhais ao longo do Itacaiúnas e de seus tributários podiam permanecer na cidade a maior parte do ano, 
ou mesmo durante o ano inteiro, e ainda assim ter a garantia de que seus agentes receberiam a castanha devida pelos coletores, aos quais haviam sido fornecidas provisões no início da temporada. Ao mesmo tempo que os proprietários dos castanhais controlavam a violência local, também reprimiam as tentativas de invasões. Porém, com o desaparecimento da hegemonia política da oligarquia local, a propriedade ausente encorajava formas alternativas de reivindicar a terra.

Os limites territoriais dos castanhais não estavam demarcados ou registrados de forma compatível com as novas tecnologias de mensuração e procedimentos legais de registro adotados pelo INCRA e pelo GETAT e, assim, os territórios abrangidos por muitos dos antigos títulos de arrendamento eram muito ambíguos. Legalmente, os títulos não podiam exceder 3.600 hectares, mas a terra era raramente medida. Muitos proprietários reivindicavam áreas entre rios particulares, que compreendiam muito mais do que os 3.600 hectares aos quais tinham direito. A existência de um título mantinha a terra sob a jurisdição do Pará e, portanto, do ITERPA. As terras que excediam os 3.600 hectares especificados nos estatutos de arrendamento eram consideradas sem dono e, portanto, revertiam à jurisdição do GETAT. A derrubada de árvores de castanha-do-pará era ilegal, tanto segundo os acordos de arrendamento originais com o governo estadual, como mais tarde conforme a legislação de conservação florestal, que adotou a proteção do Estado sobre esses recursos naturais. Não estava claro, portanto, como o GETAT iria assentar camponeses nos castanhais. A legislação protegia as árvores, não os castanhais, e onde os castanhais iniciavam e terminavam era ainda uma questão em aberto. O GETAT podia - e assim fez - ignorar a interdependência das castanheiras e da floresta circundante. Para reivindicar a terra, os camponeses tinham de limpála. O Instituto Brasileiro de Desenvolvimento Florestal (IBDF) podia preocupar-se com o fato de os camponeses deixarem ou não as castanheiras, mas o GETAT não tinha ordens para preocupar-se com o fato de que o calor, a luz e as queimadas poderiam matar as árvores.

Quando a floresta foi aberta para a ferrovia, os velhos castanhais passaram a oferecer oportunidades de criação de fazendas e de obtenção de rendimentos com a colheita. Pequenos fazendeiros começaram a comprar os velhos títulos e, em alguns casos, os proprietários originais passaram a desmatar os castanhais para fazer pasto. A situação incerta dos castanhais cujos limites físicos ultrapassavam a medida legal de 3.600 hectares abriu a possibilidade a pequenos fazendeiros, que poderiam reivindicar os lotes de 50 hectares especificados pelo GETAT, no espaço excedente. A linha férrea prometia a entrada para a terra e os meios para comerciar seus produtos. A decisão sobre quais partes de um castanhal eram consideradas excedentes era deixada, teoricamente, a cargo da dúbia autoridade e do inadequado pessoal do GETAT e, na prática, a cargo das eventualmente 
violentas acomodações entre arrendatários e invasores. O controle hegemônico que havia isolado a oligarquia de Marabá havia sido perdido com o surgimento dos novos órgãos políticos e econômicos e uma migração em massa, porém os membros da velha oligarquia continuavam utilizando a violência e outros subterfúgios para manter suas terras.

Desde 1983, o GETAT havia planejado a demarcação de duas grandes áreas de terra em pequenos lotes de assentamento ao longo da ferrovia a oeste de Marabá, porém nenhuma ação oficial havia sido tomada, e os colonos começavam a mudar-se para a área, antecipando a eventual legalização de sua posse. Muito antes dos trilhos terem sido colocados, os proprietários de castanhais, fazendeiros e pequenos proprietários já estavam lutando pela posse dessas terras. As jurisdições separadas e justapostas do GETAT e do ITERPA impediam um efetivo arbitramento desses casos, e a área ainda era muito distante de Marabá, propiciando pouca resistência à violência aberta. Quando o primeiro trem passou por ali, em 1985, conflitos sobre três diferentes castanhais, totalizando mais de 14.500 hectares (um deles com dois títulos de arrendamento separados), haviam sido registrados pelo GETAT. Em cinco meses, haviam sido detectados mais três casos; em um deles, o proprietário havia prendido, torturado e matado cinco posseiros.

As maiores tensões sobre a terra e, conseqüentemente, a maior violência ocorriam nos limites dos aproximadamente 800.000 hectares de densos castanhais. A castanha-do-pará cresce ao longo da área entre Marabá e Carajás, porém está mais concentrada na área limitada pela grande curva a leste do rio Araguaia, a uns 100 km ao sul de Marabá, na curva a oeste do rio Tocantins, depois que o rio Araguaia deságua nele, a $50 \mathrm{~km}$ rio acima e a leste de Marabá. Uma faixa mais estreita de castanhais estende-se ao norte de Marabá, ao longo da margem oriental do Tocantins, e uma ponta estreita estende-se a oeste, em direção a Carajás. Porém, os castanhais mais ricos situam-se ao sul de Marabá, ao longo dos rios que deságuam ao norte, no Itacaiúnas.

O afluxo de fazendeiros, madeireiros e pequenos proprietários camponeses para a área começou a diminuir, paulatinamente, os grandes castanhais, empurrando-os para os limites dessa enorme área e ocasionando severos conflitos entre os antigos proprietários das terras vagas do Estado e posseiros que esperavam obter vantagem das novas leis federais para legalizar suas ocupações. A jazida de Carajás foi o mais poderoso catalisador que estimulou a migração para essa área e os conflitos de terra durante o último quarto de século, porém seus efeitos foram potencializados por outros projetos na região.

\section{Outros minerais, outras frentes}

As minas de ferro e seus extensos efeitos sociais, econômicos e ambientais foram a peça central de uma grande revolução trazida pelas 
novas estratégias e pelos projetos para tornar o Pará uma província exportadora de minerais. Não somente o manganês havia sido encontrado no ano anterior à descoberta do ferro em Carajás, mas, em 1963 e novamente em 1967, grandes reservas de bauxita foram descobertas no rio Trombetas, que deságua no Amazonas a 500 milhas a oeste de Belém. Por volta de 1973, um grupo de companhias de alumínio do Japão, reunidas em um consórcio chamado Nippon Amazon Aluminium Company (NAAC), iniciou conversações e negociações com a CVRD, a fim de implantar as instalações de uma fábrica de alumínio na boca do rio Tocantins, onde ele deságua na baía do Guamá, próximo à cidade de Belém.

O Japão estava consumindo mais e mais alumínio, e o alumínio necessitava de muita eletricidade. Os preços da eletricidade, no Japão, haviam dado um salto após a crise do petróleo, em 1973. A indústria pesada estava sendo atacada naquele país por causa da poluição que causava; portanto, havia um grande incentivo para a instalação de fábricas de beneficiamento de matéria-prima fora de seu território. A idéia japonesa, fortemente apoiada pelo governo brasileiro, era construir uma grande represa hidroelétrica no rio Tocantins, a meio caminho entre Marabá e Belém, para fornecer a eletricidade necessária para transformar a bauxita e a alumina derivada em um alumínio que pudesse ser exportado para o Japão e para o resto do mundo (BUNKER, 1994).

Os planos para construir a represa foram anunciados em 1974. Por volta de 1975, os associados japoneses deixaram claro que não investiriam nem na hidroelétrica, nem no porto, que deveria ser construído para exportar a alumina e o alumínio. A essa altura, o governo brasileiro já estava econômica e politicamente comprometido com o projeto e resolveu seguir adiante com esse gigantesco plano, por sua própria conta. Em 1976, a NAAC e a CVRD formaram uma parceria para construir a fundição de alumínio.

Os trabalhos na Usina de Tucuruí iniciaram em 1977. Apesar de uma longa demora, a barragem foi fechada em 1984, começando a represar a água em um grande lago de 200 km, cuja extremidade superior quase atingia Marabá. A construção da barragem atraiu grandes contingentes de trabalhadores, e seu término deslocou tanto a população indígena, como as comunidades de camponeses das áreas a ser inundadas, deixando os recém-emigrados desempregados. Muitos dos desempossados e desempregados rumaram para Marabá. A própria represa acabou com o transporte fluvial de Marabá para Belém.

Outro mineral também teve extraordinário impacto em Marabá. Em 1980, foi descoberto ouro em Serra Pelada, cerca de 20 milhas a oeste de Marabá, muito perto, em linha direta entre Marabá e Carajás. Cerca de 40.000 mineradores acorreram à área, após a descoberta de grandes pepitas. Serra Pelada estava sendo minerada manualmente, 
como um barranco aberto. Estava sujeita a atrasos durante a estação das chuvas e a eventuais fechamentos, quando as paredes se tornavam muito íngremes e inseguras e o topo do barranco tinha de ser alargado. Em conseqüência, garimpeiros iam e vinham e, durante os períodos mais lentos, saíam em busca de áreas próximas para garimpar. Tanto a CVRD como os fazendeiros consideravam essa atividade uma ameaça às suas reivindicações de terras. O mercúrio usado para a extração do pó de ouro dos depósitos aluviais contaminava a água, diminuindo a pesca, que havia proporcionado uma importante fonte de proteína à população pobre urbana e rural ao longo do Tocantins e seus afluentes. Mais do que Carajás, Serra Pelada significou uma enorme demanda de prostituição, e brigas pela participação no ouro encontrado alastraramse para as cidades aonde os garimpeiros, mineradores e investidores, que forneciam dinheiro, iam divertir-se, comprar mantimentos e utilizar os serviços bancários. A jazida de ouro criou não somente uma grande explosão no comércio local, mas também grandes problemas de ordem social e saúde pública (SCHMINK; WOOD, 1992).

Assim, naquela manhã de 1985, o trem cruzava uma paisagem cuja vegetação havia sido substancialmente alterada, onde modelos de propriedade, comércio e transporte também haviam sido drástica e violentamente transformados e onde a economia e a topografia dos rios, das cidades e da própria terra haviam mudado de forma extraordinária.

A cidade de Marabá, que os trilhos atingiam a 163 km de distância da boca da jazida, tinha agora mais de 200.000 habitantes, doze vezes mais do que sua população durante a descoberta do minério de ferro. $\mathrm{O}$ rio Tocantins não era mais o único meio de transporte até Belém e os mercados mundiais, pois havia sido suplantado pela estrada e pela ferrovia, e a represa de Tucuruí havia cortado seu sistema único de transporte em dois sistemas menores, acima e abaixo do lago. A velha economia da castanha entrava em rápido declínio, enquanto a agricultura, a pecuária e a indústria madeireira tomavam a terra e poluíam o ar que apoiava os velhos castanhais. Os eventos políticos e econômicos no município de Marabá não estavam mais escondidos no fundo da floresta, mas estavam sujeitos ao escrutínio e a debates nacionais e internacionais.

\section{Lutas por financiamento e campanhas pelo controle}

As vastas mudanças feitas pela jazida e suas repercussões nos órgãos governamentais ocorreram muito mais rapidamente do que os sistemas administrativos locais podiam suportar. Durante a primeira década após a descoberta de Carajás, nem o governo estadual, nem os grupos empresariais locais haviam devotado muito tempo ou ponderação aos peculiares problemas sociais e econômicos e às enormes mudanças 
ambientais e demográficas que a operação da jazida traria. As lutas pelo controle da terra, os debates sobre os onerosos projetos de colonização e os argumentos políticos sobre os generosos incentivos fiscais que o governo oferecera a grandes fazendeiros e companhias madeireiras dominaram a atenção pública durante a quase totalidade da década de 70.

A primeira manifestação de preocupação local surgiu em 1975 e, mesmo assim, estava mais ligada às formas pelas quais o metal seria levado de Carajás até o mar do que aos efeitos das operações da jazida. Políticos e empresários locais favoreciam o uso de balsas no rio Tocantins. Eles pensavam em remeter o metal pelo Tocantins e carregá-lo no porto de Belém (PAES LIMA, 1975). Porém, a CVRD, a U.S. Steel e mais ainda o consórcio japonês, que passou a envolver-se cada vez mais com o projeto, queriam que a ferrovia fosse até as águas mais profundas do porto de São Luís. O acesso aos competitivos mercados europeus e japoneses exigia uma economia de escala, que somente os grandes navios poderiam oferecer. Como São Luís não fica no Pará e sim no vizinho Estado do Maranhão, as classes políticas e empresariais paraenses estavam preocupadas com o fato de que aquilo que consideravam seus recursos naturais fosse contribuir não para o desenvolvimento financeiro e econômico do seu Estado e cidade, mas para o desenvolvimento do Maranhão. Eles diziam que a ferrovia iria deixá-los apenas com um buraco no solo.

A ferrovia havia-se tornado também uma fonte de tensão entre a CVRD e o governo brasileiro e os sócios da U.S. Steel. A U.S. Steel queria que o governo brasileiro assumisse os custos da ferrovia. O governo insistia para que a AMZA financiasse a totalidade do projeto. A U.S. Steel atrasou sua parte no investimento da ferrovia. Os sócios brasileiros passaram a suspeitar que a U.S. Steel estava atrasando o desenvolvimento da jazida a fim de proteger seus próprios investimentos em ferro na Venezuela e na Austrália. Ao contrário da CVRD, a U.S. Steel tinha acesso ao minério de ferro em outros países. A entrada de Carajás como um grande fornecedor de ferro no mercado mundial poderia baixar os preços e, portanto, reduzir os lucros nessas outras jazidas. A CVRD acusava a U.S. Steel de utilizar a estratégia de "jazida presa", mantendo Carajás como um recurso inativo para uso futuro. Como conseqüência desses desentendimentos, a CVRD comprou, em 1977, as ações de propriedade da U.S. Steel, por cinqüenta milhões de dólares e começou a procurar novos sócios.

O ano de 1977, porém, não foi um ano propício para que uma companhia brasileira fizesse grandes e novos investimentos. A economia brasileira, que havia florescido entre 1968 e 1973, estava agora sofrendo as conseqüências do extenso endividamento. A campanha maciça pela industrialização e o choque do petróleo, em 1973, haviam inflacionado o já considerável débito brasileiro. O país dependia do petróleo importado 
e seu modelo industrial enfatizava tecnologias intensivas em energia. Primeiramente, a CVRD e o governo brasileiro tentaram atrair investidores estrangeiros diretos para dividir alguns dos custos da jazida. Devido à crise do petróleo, que havia feito um considerável estrago na balança de pagamentos do Brasil, o mercado mundial de aço também se encontrava em recessão e havia pouca manifestação de interesse no empreendimento. O governo brasileiro decidiu, então, fazer da necessidade uma virtude: proclamou que os depósitos eram tão valiosos que a companhia brasileira CVRD manteria o controle total sobre eles.

O problema passou a ser, então, encontrar fontes externas de crédito. O governo havia autorizado e encorajado a continuação dos trabalhos da ferrovia e na própria jazida, por meio de capital local, obtido com empréstimos e venda de ações. Por volta de 1980, estava tornandose um problema urgente a busca de recursos externos para os investimentos projetados em quase cinco bilhões de dólares, 60\% dos quais eram necessários para a ferrovia. Vários contratos de longo prazo foram assinados com compradores europeus e japoneses para o aço. Foram feitas tentativas de acordo nos contratos para que houvesse financiamento parcial por cada um desses grupos. Porém, foi só depois de 1980, quando o Banco Mundial colocou seu selo de aprovação no projeto, aprovando um empréstimo de fundos próprios no valor de trezentos milhões de dólares e coordenando as negociações entre os demais emprestadores em potencial, que os acordos de financiamento finalmente decolaram. O empréstimo foi aprovado um pouco antes que a crise da dívida mexicana, em 1982, colocasse a maior parte dos empréstimos a países latinoamericanos altamente endividados em compasso de espera.

Direitos indígenas, proteção ambiental e empréstimo internacional ${ }^{3}$

A crítica mundial aos efeitos do desenvolvimento sobre o meio ambiente e sobre os grupos indígenas havia produzido algum efeito, embora pequeno, nos centros financeiros mundiais, e projetos de empréstimo tinham de levar esses aspectos em consideração. Tanto a Comunidade Européia como o Banco Mundial condicionaram seus empréstimos a que a CVRD implantasse medidas para proteger o ambiente físico e os direitos dos grupos indígenas. A implantação dessas medidas pela CVRD nas treze áreas indígenas identificadas como áreas afetadas pela ferrovia foi grandemente criticada. Os assuntos mais controversos giravam em torno da reserva Mãe Maria, onde se haviam criado complexas relações entre direitos ambientais, direitos indígenas, reforma agrária e direitos estaduais.

\footnotetext{
${ }^{3}$ Funcionários do GETAT e do INCRA permitiram-me que os acompanhasse a reuniões com a Fundação Nacional do Índio (FUNAI), o IBDF e a CVRD. Essas reuniões e as subseqüentes entrevistas nos órgãos participantes formam a base para a discussão que se segue.
} 
Não muito distante de Marabá e além da ponte de $2 \mathrm{~km}$ e meio sobre o Tocantins, o trem entrava na reserva indígena de Mãe Maria, lar dos índios Gavião. Mãe Maria foi assim chamada devido ao grande castanhal que havia sido explorado por uma única família desde 1923. Parte desse castanhal havia sido cedida aos índios, que haviam sido transferidos de uma área mais a leste, em 1947. A instalação das linhas de transmissão de Tucuruí e posteriormente a abertura da ferrovia haviam estimulado uma invasão em massa de pequenos proprietários e criado um conflito entre proprietários de terra, proprietários portugueses e os novos camponeses e entre estes e os índios, que por sua vez haviam explorado comercialmente a castanha-do-pará e que se haviam oposto à ferrovia e às linhas de transmissão, que cortavam seu território, porém não haviam sido capazes de evitar esse novo avanço. A ferrovia, cortando o território Gavião em Mãe Maria, era, portanto, um assunto particularmente delicado.

A CVRD rapidamente começou a trabalhar com a FUNAI, a Fundação Nacional do Índio, e com o GETAT, o Grupo Executivo das Terras do Araguaia-Tocantins, para garantir aos índios Gavião que os posseiros portugueses em sua área seriam removidos e transferidos para outras áreas. O reassentamento dos posseiros que haviam invadido terras indígenas protegidas levantava difíceis questões políticas, legais e ambientais. O GETAT estava preocupado em não estimular outras invasões ao recompensar os invasores de áreas proibidas com títulos de propriedade em outras áreas. As únicas áreas perto de Marabá que haviam restado para assentamentos eram os castanhais. O GETAT não estava particularmente preocupado com a legislação ambiental que protegia as árvores, porém o envolvimento da CVRD tornou o aspecto ambiental mais saliente. Os castanhais eram as únicas terras ao redor de Marabá que ainda estavam sob a jurisdição do Estado do Pará.

Jader Barbalho, o governador do Pará, havia-se comprometido publicamente a reclamar a jurisdição estadual sobre as terras devolutas. Isso fazia parte de uma retórica populista, facilitada pelo relaxamento do controle militar e pela promessa de alguma descentralização. Barbalho criticava abertamente seu antecessor por haver feito muitas concessões à CVRD. Os arrendatários de castanhais acharam conveniente aliar-se ao Estado do Pará e ao IBDF contra o GETAT e a CVRD. O governo estadual não estava, portanto, muito inclinado a permitir que o GETAT expropriasse os castanhais para reassentar os posseiros. Os índios Gavião queriam apenas a rápida remoção dos invasores, a mesma solução buscada pela CVRD, especialmente quando os Gavião começaram a ameaçar bloquear a ferrovia se a demora na remoção dos invasores continuasse. A CVRD temia a interrupção das vendas e o embaraço internacional causado por um protesto indígena direto. A companhia aumentou suas pressões nos órgãos estaduais e federais para uma rápida solução. 
Florestas, castanha-do-pará, índios, camponeses e ferrovia tornaram-se símbolos da terra e do uso da terra, incorporados e representativos de diferentes relações de poder entre grupos definidos de forma regional, étnica e econômica. Diferentes interesses políticos e econômicos eram manifestados por meio da manipulação desses símbolos, de forma que, muitas vezes, distorciam-se as relações entre os grupos ou os atores que os invocavam e as pessoas ou as coisas que os símbolos representavam. Por exemplo, o governador do Pará utilizou o significado ambiental das castanheiras a fim de defender os direitos do Estado sobre a terra, mesmo que tal estratégia o aliasse aos proprietários de castanhais, que também invocavam princípios ecológicos a fim de manter o controle pessoal sobre essa mesma terra. Essa aliança com uma oligarquia proprietária de terras, baseada na coerção de mão-de-obra endividada, era muito estranha para um governo publicamente comprometido com a reforma agrária e dependente do apoio das organizações trabalhistas de esquerda. Da mesma forma, os ambientalistas, normalmente simpáticos às reivindicações territoriais dos grupos indígenas, estavam agora em uma estranha situação ao negar aos camponeses que ocupavam as terras dos Gavião o acesso às terras de outros castanhais. Eles eram vistos como grupos desejosos de subordinar as necessidades dos camponeses e dos índios à proteção da floresta. O interesse do GETAT era simplesmente encontrar uma rápida solução para o reassentamento dos camponeses. Sujeita às pressões internacionais para assegurar a proteção do meio ambiente e dos grupos indígenas, a CVRD estava suscetível às demandas de todos os órgãos com jurisdição sobre parte dos recursos necessários à solução do problema. Como a maior parte desses órgãos via a CVRD como a raiz do problema, sentiam-se plenamente justificados em chamar a CVRD a assumir a maior parte das despesas, o que era muito mais do que a companhia estava disposta a assumir.

Todas essas polêmicas manobras políticas foram executadas em razão do conflito entre dois diferentes modos de extração de recursos naturais em um mesmo ambiente. A extração de castanha-do-pará era mais antiga, dependia de uma planta auto-regenerativa, necessitava muito menos investimento de capital e havia engendrado uma organização social de trabalho e uma distribuição de acesso aos recursos que epitomavam os aspectos mais retrógrados e repreensíveis do subdesenvolvimento de uma economia "tradicional". Dessa maneira, os castanhais representavam tudo aquilo que uma sociedade consciente e modernizada havia-se comprometido a acabar. Ao mesmo tempo, a exploração da castanha-do-pará necessitava de pouquíssimo capital externo, protegia o meio ambiente natural, dependia de uma bela e nobre árvore, que simbolizava para muitos o ideal de um relacionamento auto-sustentado entre os seres humanos e a natureza, e era controlada 
localmente. A jazida de minério era a representação da modernidade, da alta tecnologia, da organização racional do trabalho, baseada em posições burocráticas, em qualificações técnicas e em salários regulamentados, e da conexão com o resto do mundo. Esses dois modos de extração eram localizados de tal modo que afetavam e utilizavam o mesmo espaço. Suas diferenças levaram-nos a um conflito direto, tanto como símbolos, quanto como operações físicas.

\section{Ferro e castanha-do-pará no espaço e na economia}

O vívido contraste entre as máquinas e a selva, a floresta e o desmatamento, a estática e as mudanças, engendrado pela ferrovia e pela passagem do trem ao longo dela, derivou de conflitos e de incongruências mais fundamentais, que não eram tão fáceis de ser percebidos como aqueles ocorridos ao longo da linha férrea. Minério de ferro e castanha-do-pará sustentavam em seus ombros um importante conjunto de desuniões. Ambos eram bens extrativos. Ocorriam na natureza anteriormente à intenção humana ou à manufatura. Ambos haviam causado o ímpeto primário de ocupação humana do espaço ao redor dos locais onde estavam situados. Ambos eram extraídos, em princípio, mais para a exportação do que para o consumo ou a transformação local. De todas essas maneiras, ambos representavam um dos mais importantes fatores determinantes do subdesenvolvimento regional - a dependência primária da exportação de uma matéria-prima. O minério de ferro e a castanha-do-pará transformaram suas economias regionais em tomadores e não em formadores de preços; suas posições nos mercados mundiais eram inteiramente determinadas pela demanda externa à região, não pelas preferências e pelas estratégias da sociedade local.

Como commodities, porém, suas situações na economia mundial são totalmente diferentes, assim como sua localização no ecossistema local. Mais obviamente ainda, seus fins ou valores de uso são bastante distintos. O minério de ferro é transformado em uma infinita quantidade de formas e tamanhos e mistura-se a vários outros minerais em processos multifacetados. A castanha-do-pará presta-se a muito pouco processamento, além da remoção dos duros ouriços nos quais crescem e da posterior remoção da castanha. Isso significa que o minério de ferro pode absorver - e realmente o faz - uma grande quantidade de mão-de-obra, em diferentes processos de transformação de material, que podem ser - e realmente o são - realizados em diversos locais, organizações e composições de trabalho e capital. A castanha-do-pará, por outro lado, absorve muito pouca mão-de-obra em sua passagem da árvore para o consumidor. A mão-de-obra que absorve faz muito pouco para transformar a matéria-prima. O trabalho simplesmente muda a localização da fruta, primeiramente mudando-a de lugar tanto do ouriço como da casca e depois no espaço. 
Os modos de utilização do trabalho na extração da castanha-dopará são pouco suscetíveis a mudanças tecnológicas, além das tecnologias de transporte, enquanto a grande gama de usos do minério de ferro expõe esse recurso a um número muito maior de oportunidades de mudança tecnológica e de intensificação de capital, que normalmente acompanha as mudanças tecnológicas. O ferro é um ingrediente fundamental para vários processos industriais, de forma que o seu preço tem repercussões em toda uma economia industrial, afetando níveis de lucro e taxas de inflação e entrando nas estratégias capitalistas de utilização do trabalho e do capital em relação a si mesmos e à matériaprima que costumam transformar. A demanda mundial por minério de ferro aumentou devido à produção industrial mundial, que está em expansão. Por essas duas razões, a mineração do ferro tornou-se mais intensiva em capital durante as últimas décadas. A intensidade de capital requer operações de mineração em larga escala. A extração em larga escala requer grandes depósitos, os quais são relativamente poucos e não ocorrem, normalmente, perto dos centros populacionais; podem antes ocorrer em áreas tão remotas e difíceis como a de Carajás. O resultado disso é que grandes quantidades de peso e volume são transportadas ao longo de grandes porções de espaço. É devido a esse fator de peso e volume que o ferro concorre diretamente com a castanhado-pará em Marabá. Se o ferro pudesse ser retirado com a mesma pouca infra-estrutura humana necessária à castanha-do-pará, a maciça migração para a área não teria ocorrido. O grande volume de capital enterrado no complexo da jazida requer uma complexa coordenação entre grandes firmas nacionais e internacionais e os Estados, de forma que os interesses envolvidos são muito mais poderosos do que qualquer outro presente na economia local.

Tudo isso pode parecer óbvio, mas é preciso apontar, pois não estamos ainda muito acostumados a pensar sobre os modos como a natureza das commodities estrutura as relações de trabalho e o uso do capital que são absorvidos por elas, nem costumamos pensar muito sobre as grandes diferenças nas maneiras como as economias extrativas estão localizadas no tempo e no espaço. As economias industriais são localizadas, em princípio, em decorrência de decisões sociais, mesmo que estas levem em consideração as características naturais de uma paisagem. Os empresários tendem a localizar suas fábricas e escritórios de acordo com a localização de outras atividades sociais e também de acordo com o resultado dessas localizações, tais como o preço dos terrenos e a proximidade dos meios de transporte, comunicação ou energia. Economias extrativas precisam estar localizadas na fonte da matéria-prima extraída. Decisões sobre como transportar essa matériaprima ou onde instalar fábricas de beneficiamento são mais suscetíveis à determinação social, mas a forma original da matéria-prima, sua 
composição química, sua estrutura molecular e sua mistura com outros materiais continuam a pesar diretamente sobre as escolhas subseqüentes. Fatores naturais, tanto a forma material, como a localização geográfica, pesam mais em economias extrativas do que nas industriais. Menos capazes de manipular as fontes fundamentais de valor, sociedades organizadas em torno da extração para exportação tendem a permanecer subordinadas, em primeiro lugar, aos processos naturais do ecossistema local, que podem realmente aumentar os efeitos da desestruturação ambiental pertinentes à extração, e, em segundo lugar, à vacilação da demanda e do preço nas economias industriais, nas quais fatores sociais, desde a preferência dos consumidores até as inovações tecnológicas, são muito mais determinantes do que nas economias extrativas, ligadas à natureza.

A subordinação da economia extrativa à industrial deve-se às complexas e paradoxais relações entre a sociedade humana e a natureza física e entre as regularidades moldadas ou baseadas em leis da economia e da física. E, termos físicos, a produção social não pode ocorrer sem a matéria produzida na natureza. A sociedade pode, assim, ser vista como parte da natureza, dependente dela e somente capaz de produzir ao subordinar o trabalho humano e as técnicas às leis da física, descobertas na matéria e através dela. A sociedade também pode ser vista como utilizando o trabalho e a técnica para usar a natureza, como matéria, como espaço e como força para atingir propósitos humanos, subordinando, assim, a natureza.

Em um nível menos abstrato, o mesmo paradoxo emerge dos efeitos das doações de um recurso natural sobre o desenvolvimento regional. Um recurso rico pode promover um desenvolvimento diversificado, autosuficiente e industrial, levando a uma prosperidade regional e nacional, mas a extração de um recurso natural também pode causar um dano terrível ao ambiente físico e às comunidades humanas, à flora e à fauna, que dependem dele para sua subsistência e seu conforto. O carvão na Inglaterra, as florestas da Nova Inglaterra e o petróleo do Texas proporcionaram um rápido crescimento econômico, porém as profundas cicatrizes deixadas nas montanhas Appalache e a opressiva pobreza de muitos de seus habitantes atestam os altos custos de fornecer matériaprima para a transformação industrial. As análises dos estudiosos das economias extrativas de recursos demonstram esse marcante contraste. Para alguns, a abundância de matéria-prima atrai empresários dinâmicos e trabalhadores qualificados e o dinheiro auferido com a exportação desses bens torna-se o capital para o crescimento da produção industrial, permitindo, eventualmente, que a região exportadora do recurso transforme sua própria matéria-prima e consuma seus próprios produtos manufaturados dentro de sua própria economia em expansão e autosuficiente. Para outros, a exportação de matéria-prima condena as 
economias da região a ciclos alternados de prosperidade e colapso econômico, pois as flutuações de mercado e de preços e a eventual exaustão do recurso exportado criam um constante deslocamento fiscal e social, que impede a integração entre produção e consumo, deixando a economia extrativa dependente de economias produtivas, localizadas em outros lugares, que processam suas próprias matérias-primas.

Esses exemplos nas trajetórias de diferentes economias extrativas são suficientes para defender qualquer uma das posições. Utilizar outros casos para prever o impacto de Carajás e da economia e da sociedade nacional, regional e local requer uma especificação precisa do tipo de commodities extraídas, de sua posição e de seu papel dentro de seu ambiente natural e social, da organização política em âmbito local, regional e nacional e da atuação dos mercados financeiro e de commodities no momento em que o empreendimento específico está sendo desenvolvido. A análise corporativa do modo como as diferentes economias extrativas afetam seu ambiente físico e social fornece alguns insights sobre a elaboração dos planos e iniciativas de projetos para a exploração de Carajás, porém, Carajás é também um caso único. Não somente por ser uma das mais ricas reservas minerais e vegetais do mundo, mas também por estar localizada em um dos mais complexos e vulneráveis ecossistemas do mundo.

O governo brasileiro amarrou o desenvolvimento das jazidas nessa área, seu Projeto Grande Carajás, a um conjunto de ambiciosos programas para integrar o desenvolvimento industrial e agrícola, investindo pesadamente na construção de estradas, ferrovias, portos, hidroelétricas, linhas de transmissão, sistemas de comunicação e novas cidades inteiras, a fim de capturar e ampliar os resultados econômicos e sociais na riqueza natural da região. Nesse processo, o país aumentou sua dívida externa e seu déficit interno, interrompendo drasticamente a organização física e social das populações existentes e causando danos irreversíveis ao meio ambiente. Ao mesmo tempo, seus numerosos projetos geraram muitos empregos, causaram uma explosão no setor de construção, atraíram profissionais qualificados a uma região onde poucos existiam e aumentou o consumo interno e as exportações na região. A forma e a distribuição dos incentivos e gastos do governo e o previsível resultado dos programas governamentais ainda estão sendo intensamente debatidos por políticos, planejadores, empresários e intelectuais, em âmbito local e nacional.

Muitos aspectos dos programas já foram irreversivelmente estabelecidos. Represas, estradas e portos já estão prontos, e uma grande variedade de onerosos incentivos fiscais já foi concedida. Outras partes dos programas estão sendo ainda negociadas e os resultados dessas negociações afetarão profundamente a riqueza e o poder das atuais comunidades e facções em competição. Além disso, o desenvolvimento da jazida coincidiu com grandes mudanças na economia mundial e com a situação do Brasil dentro dela. A economia brasileira, sua dívida 
internacional e o déficit de seus Estados levantaram questões durante o período em que a jazida estava vindo à tona. Simultaneamente, grandes debates estavam sendo conduzidos sobre o retorno ao regime civil e sobre o desequilíbrio entre as forças do poder central e as forças estaduais. Tudo isso causou tremendos impactos na forma como Carajás foi planejado.

A história definitiva da região mineral de Carajás ainda levará muitos anos para ser escrita. O propósito deste estudo é simplesmente interpretar a primeira parte dessa história, demonstrando as possíveis trajetórias das economias extrativas, e contribuir para o contínuo debate sobre o modo mais benéfico e menos prejudicial de explorar recursos naturais, que constituem os insumos essenciais para as sociedades industriais, que os transformam para o uso e o lucro dos seres humanos. Os projetos minerais em Carajás e os projetos de desenvolvimento a eles associados são os maiores, mais audaciosos e potencialmente os mais calamitosos planos de desenvolvimento econômico que o Brasil jamais executou. A área a ser afetada por esses planos está modificando-se rapidamente, e os impactos ainda estão se acelerando. Esses efeitos podem exemplificar aspectos importantes das mudanças sociais e econômicas, planejadas ou não, no Brasil e no mundo, porém o enorme tamanho e a complexidade próprios da região, bem como os vários empreendimentos que estão trazendo essas mudanças, estão muito além dos objetivos deste estudo.

A história de Carajás apresenta dois processos: primeiro, a combinação de percepções, objetivos, barganhas e acomodações por trás das decisões que estruturaram o projeto de minério de ferro e o Projeto Grande Carajás; segundo, os efeitos sociais, econômicos e ambientais dos próprios projetos. Como os projetos são implementados constitui um importante componente que intervém entre essas decisões e seus efeitos. Outro fator importante nas decisões tomadas são os modos pelos quais diferentes grupos reagem às informações recebidas. Órgãos governamentais, corporações, grupos políticos e outras poderosas organizações são capazes de manipular informações que estimularão a ação de terceiros. Os planos do governo e das empresas devem ser elaborados e publicados mais para estimular respostas do que para ser um mapa autêntico de ações coordenadas. Uma vez anunciado, um plano tem uma certa autonomia e pode comprometer seus colaboradores de forma inesperada. Assim, o Estado ou a CVRD, ou algum outro grupo pode publicar um plano ou projeto para motivar terceiros, ou para se autolegitimar, e então ter de cumprir aquilo que foi percebido como seus próprios compromissos. Outros grupos ou facções interessados podem criar e manipular essa aparência de compromisso, forçando seus oponentes a fazer coisas que haviam implicitamente prometido, mas não tinham a total intenção de cumprir. As intenções por trás dos planos são freqüentemente difíceis de decifrar, pois os planos podem ter efeitos bastante significativos e bastante distintos das intenções iniciais. 
Concentrar-nos nesses efeitos permite-nos avaliar a extensão dos diferentes custos e benefícios atribuídos a um dos projetos ou a ambos. Essa iniciativa é teoricamente importante em qualquer tentativa para entender Carajás dentro de um modelo geral de economias extrativas ou utilizá-lo para especificar esse modelo mais precisamente. É também importante na prática, pois os benefícios do empreendimento de mineração podem estar direcionados, em princípio, à economia nacional, ou a alguns dos seus setores, enquanto os custos serão impingidos, em princípio, à população e ao meio ambiente locais. Em um sistema federativo, como o do Brasil, isso pode muito bem significar que os governos estaduais terão de arcar com o rápido aumento dos custos ou das necessidades para o bem-estar social, que excedem, em muito, a arrecadação adicional que a economia extrativa pode proporcionar.

Ao mesmo tempo, é importante analisar os processos de tomada de decisão em torno do empreendimento de mineração, pois decisões políticas e econômicas também determinam os efeitos da jazida, dentro dos limites ou obstáculos criados pelas características e pelas dinâmicas específicas desse processo extrativo. A fim de entender os modos pelos quais as economias extrativas afetam a trajetória do desenvolvimento regional, é necessário entender as restrições que podem ser impostas ao planejamento e à execução dos planos e os interesses e estratégias conflitantes e colaboradores, utilizados pelos diferentes grupos para aumentar sua influência nessas decisões. Para isso, é importante entender como esses grupos percebem sua própria posição e seus interesses dentro da situação geral. Essa questão é particularmente interessante à luz das tentativas de grupos de interesses diferentes em basear seus argumentos em apelos a concepções distintamente idealizadas do bem, definidos em âmbito regional ou nacional, elaborados a partir de modelos ecológicos, econômicos, sociais ou culturais, de proveniência técnica ou acadêmica e, assim, dotá-los da legitimidade dada ao conhecimento especializado.

A jazida produz uma série de efeitos, alguns positivos, outros negativos, distribuídos desigualmente entre diferentes populações, classes e ambientes físicos. Os efeitos físicos diretos da jazida são previsíveis dentro de um modelo adequado de economias extrativas, devidamente especificado para as condições ambientais circundantes, incluindo relações entre ecossistemas, topografia, distribuição espacial das populações e suas economias, regime político, leis de propriedade inerentes à terra e aos recursos, grau da intensidade de capital na economia como um todo, e as características particulares do bem a ser extraído e sua localização na economia mundial, naquele momento. Esses efeitos previsíveis ou diretos, porém, são, por seu turno, mediados por decisões políticas e econômicas externas ao processo extrativo. No caso de Carajás, essas decisões foram tomadas como concessões ou 
compromissos com outros grupos que controlavam algum elemento importante na distribuição geral do poder, recursos, ou prestígio, ou como tentativas separadas para utilizar as modificações de atividades ou modificações ambientais ocasionadas pela atividade da jazida para fomentar resultados sociais, econômicos ou ambientais desejados por um ou mais grupos.

\section{REFERÊNCIAS}

AB'SABER, A. N. The paleoclimate and paleoecology of Brazilian Amazonia. In. Biological Diversification in the Tropics. New York:Columbia University Press., p. 41-59. 1982.

BUNKER, Stephen G.. Flimsy, joint ventures in fragile environments. In: BARHAM, Bradford, BUNKER, Stephen G., O'HEAR, Denis (Ed.). States, firms, and raw materials: the world economy and ecology of aluminum. Madison: University of Wisconsin Press, p. 261-296. 1994.

EMMI, Marília Ferreira. Oligarquia do Tocantins e o domínio dos castanhais. 2.ed. rev. ampl. Belém : NAEA/UFPA, p. 174. 1999.

PAES, J. Lima. Escoamento do minério dos Carajás: hidrovia ItacaiúnasTocantins. Belém, PA: Falangola, p. 69. 1975.

SANTOS, Breno Augusto dos. A realidade do potencial mineral. Ciência Hoje, Rio de Janeiro, v. 1, n. 3, p. 37-40, mar., 1983.

SCHMINK, M. e WOOD, C. H. "Contested Frontiers in Amazonia". New York, Columbia University Press, p. 385. 1992. 